\title{
Endobronchial anthracosis with concurrent primary lung cancer
}

\author{
Pichapong Tunsupon, ${ }^{1}$ Anthony Picone, ${ }^{2}$ Jessie Bower, ${ }^{3}$ Abdul Hamid Alraiyes ${ }^{1,4}$
}

${ }^{1}$ Department of Medicine, University at Buffalo State University of New York School of Medicine and Biomedical Sciences, Buffalo, New York, USA

2Department of Thoracic Surgery, Roswell Park Cancer Institute, Buffalo, New York, USA

${ }^{3}$ Department of Pathology, Roswell Park Cancer Institute, Buffalo, New York, USA ${ }^{4}$ Department of Interventional Pulmonology, Roswell Park Cancer Institute, Buffalo, New York, USA

\section{Correspondence to} Dr Pichapong Tunsupon, ptunsupon@gmail.com

Accepted 10 February 2016

\section{DESCRIPTION}

An 86-year-old man was evaluated for asymptomatic persistent right upper lung (RUL) consolidation measuring $4 \times 5 \mathrm{~cm}$. He had worked as a welder in an automobile plant for 40 years and had, without protective gear, been exposed to smoke and dust from combustion of fuels. He had quit smoking 15 years prior to the work up for lung consolidation, with a previous 10 pack-year cigarette smoking history. He denied travelling to endemic areas of tuberculosis and sick contact exposure. His medications included hydrochlorothiazide and lisinopril for blood pressure control. Physical examination and laboratory work up were unremarkable. RUL consolidation and non-specific mediastinal lymphadenopathy were noted in the chest CT during the patient's 3-month follow-up. Pathological examination obtained from transbronchial biopsy of the RUL lesion revealed invasive adenocarcinoma. Cytological examination of the paratracheal lymph nodes revealed anthracotic pigmented laden macrophages against a background of lymphocytes, without evidence of malignant cells (figure 1). An incidental finding of black pigmentation lining the bronchial mucosa was demonstrated (figure 2). Bacterial, acid-fast and fungal stain from RUL bronchoalveolar lavage and paratracheal lymph node were negative.

We demonstrate the bronchoscopic findings of a man, a welder for 40 years, who exhibited occupation-related endobronchial anthracosis and anthracotic mediastinal lymphadenopathy with a concurrent stage IIa primary lung adenocarcinoma. The term 'anthracosis' describes a deposition of inhaled carbon particles in the airways, which commonly occurs in cigarette smokers and individuals working in a heavily polluted atmosphere. Most of the carbon particles are removed by mucociliary clearance and macrophages, which later deposit in the mediastinal lymph nodes. ${ }^{1}$ The residual particles remain in the bronchial mucosa. ${ }^{1}$ The data on the cause-effect relationship between lung cancer
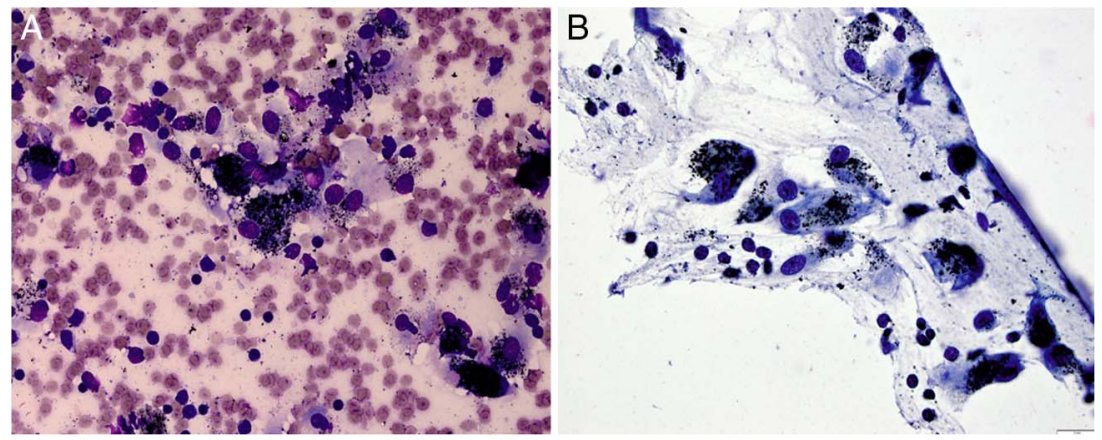

Figure 1 Mediastinal lymph node cytology obtained from endobronchial ultrasound with fine-needle aspiration (EBUS-FNA) demonstrating black pigmentation of anthracotic macrophages on a background of lymphocytes; $40 \times(A)$ and $600 \times$ original magnification Wright Giemsa stain (B).

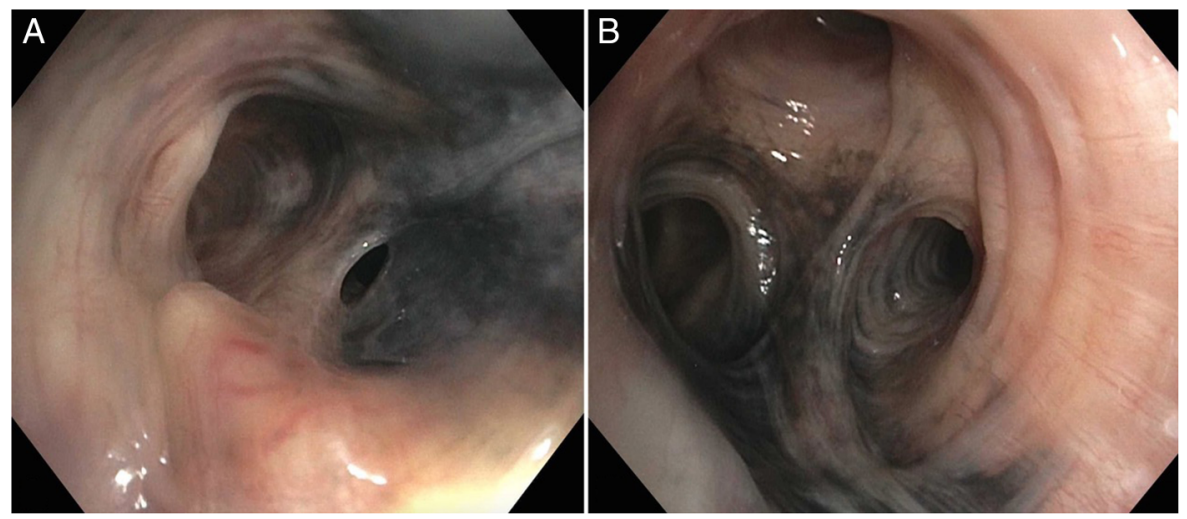

To cite: Tunsupon $P_{\text {, }}$ Picone A, Bower J, et al. BMJ Case Rep Published online: [please include Day Month Year] doi:10.1136/ bcr-2016-214649
CrossMark

Figure 2 Bronchoscopic examination demonstrating black-brown pigment lining the endobronchial mucosa mainly at the right middle lobe bronchus $(A)$ and right upper lobe bronchus $(B)$. 


\section{Learning points}

- Most of the carbon particles in the endobronchial trees are removed by mucociliary clearance and macrophages, which later deposit in the mediastinal lymph nodes. The residual particles remain in the bronchial mucosa causing endobronchial hyperpigmentation.

- The cause-effect relationship of endobronchial anthracosis or anthracotic mediastinal lymphadenopathy and primary lung cancer is not clearly elucidated, and requires further investigation.

and anthracosis are heterogeneous and not clearly elucidated. ${ }^{2}$ Detailed history of exposure to inciting agents and exclusion of other possible aetiologies, for example, infections, neoplasms and side effects of certain medications, is key to establish a diagnosis. ${ }^{3}$ There is no specific treatment for endobronchial anthracosis.

Contributors PT, AP, JB and AHA prepared the manuscript or revised it critically for important intellectual content, and approved the final version before submission to the journal.

Competing interests None declared.

Patient consent Obtained.

Provenance and peer review Not commissioned; externally peer reviewed.

\section{REFERENCES}

1 Vorwald A. The pneumoconioses and other occupational lung disease. In: Spencer $H_{\text {, }}$ ed. Pathology of the lung. 4th edn. Oxford: Pergamon 1985:413-510.

2 Mirsadraee M. Anthracosis of the lungs: etiology, clinical manifestations and diagnosis: a review. Tanaffos 2014;13:1-13.

3 Tunsupon P, Panchabhai TS, Khemasuwan D, et al. Black bronchoscopy. Chest 2013;144:1696-706.

Copyright 2016 BMJ Publishing Group. All rights reserved. For permission to reuse any of this content visit http://group.bmj.com/group/rights-licensing/permissions.

BMJ Case Report Fellows may re-use this article for personal use and teaching without any further permission.

Become a Fellow of BMJ Case Reports today and you can:

- Submit as many cases as you like

- Enjoy fast sympathetic peer review and rapid publication of accepted articles

- Access all the published articles

- Re-use any of the published material for personal use and teaching without further permission

For information on Institutional Fellowships contact consortiasales@bmjgroup.com

Visit casereports.bmj.com for more articles like this and to become a Fellow 